\title{
Biological variations of lysozyme concentration in the tear fluids of healthy persons
}

\author{
D K SEN AND G S SARIN \\ From the Department of Ophthalmology, Maulana Azad Medical College, Lok Nayak Jai Prakash Narain. \\ Hospital, and Guru Nanak Eye Centre, New Delhi, India
}

SUMmARY Concentration of tear lysozyme was measured in healthy Indian subjects of the same racial group aged 2 to 78 years by a single radial immunodiffusion technique. Variations in its concentration between the two eyes, during the day, over a period of time, in both sexes, and in different age groups were studied. The diurnal and age-related changes in the concentration of tear lysozyme were found to vary to an appreciable extent. The mean lysozyme concentration in tears was lower in the morning and higher in the evening. It tended to be low in children under 16, rose and attained a plateau in the age group 16-45 years and fell in later life, though still remaining higher than in the children.

Lysozyme, discovered by Fleming,' is widely distributed in nature. It has been found in measurable quantity in tears, saliva, serum, nasal secretions, urine, neutrophils, and macrophages. ${ }^{2}$ Since alteration in the lysozyme level in human tears has been observed in some ocular diseases, ${ }^{3-12}$ its measurement can be of considerable diagnostic importance. However, an adequate knowledge of the biological variations is essential for valid comparisons of tear lysozyme levels between healthy and diseased subjects.

The present study was undertaken to find out differences, if any, in the tear lysozyme concentration between the two eyes and also the diurnal variation in the same eye. The concentrations of tear lysozyme over a period of time and in relation to age and sex have also been studied.

\section{Material and methods}

The study was carried out on healthy Indian subjects belonging to the same racial group. They were either volunteers or had attended the outpatient department of Guru Nanak Eye Centre, New Delhi, for refraction. They had no ocular or systemic disease. All of them had been in the uniform hospital environment for at least two hours prior to sampling.

In the first part of the study tear samples were

Correspondence to Dr D K Sen, V/4, Maulana Azad Medical College Campus, Kotla Road, New Delhi-110 002, India. taken separately from each eye of 26 individuals at the same time to study any variation in the lysozyme level between the two eyes. In the second part of the study tear samples were obtained from the right eye in 18 individuals at four-hourly intervals from 6 am to $10 \mathrm{pm}$ to determine diurnal changes while in the hospital environment. Tear samples (right eye, 10 am) from 22 individuals were taken on six different occasions (alternate months) to study variation with time during a period of one year. Finally, for age-sex related changes tear samples (right eye, $10 \mathrm{am}$ ) were obtained from 319 individuals (Table 1).

The tear samples were collected by a method described previously. ${ }^{13}$ The samples were stored at $-20^{\circ} \mathrm{C}$ until assayed which was done within three to four days of collection. The level of tear lysozyme

Table 1 Distribution of tear lysozyme level in $\mathrm{mg} / \mathrm{ml}$ in the two sexes in different age groups

\begin{tabular}{|c|c|c|c|c|c|c|c|}
\hline \multirow{2}{*}{$\begin{array}{l}\text { Age in } \\
\text { years }\end{array}$} & \multicolumn{2}{|l|}{ Males } & \multicolumn{2}{|c|}{ Females } & \multirow[t]{2}{*}{$t$} & \multirow[t]{2}{*}{$d f$} & \multirow[t]{2}{*}{$p$} \\
\hline & $\begin{array}{l}\text { No. of } \\
\text { cases }\end{array}$ & Mean $\pm S D$ & $\begin{array}{l}\text { No. of } \\
\text { cases }\end{array}$ & Mean $\pm S D$ & & & \\
\hline $2-15$ & 35 & $0.81 \pm 0.31$ & 25 & $0 \cdot 84 \pm 0 \cdot 22$ & 0.41 & 58 & $>0.60$ \\
\hline $16-30$ & 50 & $1.68 \pm 0.66$ & 37 & $1 \cdot 65 \pm 0.70$ & $0 \cdot 20$ & 85 & $>0.80$ \\
\hline $31-45$ & 50 & $1.59 \pm 0.54$ & 34 & $1.61 \pm 0.54$ & $0 \cdot 16$ & 82 & $>0.80$ \\
\hline $46-60$ & 37 & $1 \cdot 30 \pm 0 \cdot 37$ & 26 & $1 \cdot 19 \pm 0 \cdot 33$ & $1 \cdot 19$ & 61 & $>0.20$ \\
\hline $61-78$ & 15 & $1 \cdot 01 \pm 0 \cdot 40$ & 10 & $1 \cdot 00 \pm 0.24$ & 0.07 & 23 & $>0.90$ \\
\hline
\end{tabular}

SI conversion: $\mathrm{mg} / \mathrm{ml}=\mathrm{g} / \mathrm{l}$. 
was measured by a single radial immunodiffusion technique. ${ }^{14}$ Monospecific rabbit antihuman lysozyme serum and reference standard were obtained from Kallestad Laboratories, USA. A standard curve was constructed for each plate, and the concentration of tear lysozyme was determined with reference to the standard curve.

\section{Results}

The lysozyme level in tears in 26 individuals were: right eye: $1 \cdot 31 \pm 0 \cdot 49 \mathrm{mg} / \mathrm{ml}$ and left eye: $1 \cdot 27 \pm 0 \cdot 41$ $\mathrm{mg} / \mathrm{ml}$. There was no statistically significant difference in the mean lysozyme level in tears between the two eyes $(t=0.81$ for $25 \mathrm{df}, \mathrm{p}>0.40)$. (SI conversion: $\mathrm{mg} / \mathrm{ml}=\mathrm{g} / \mathrm{l}$.)

The tear lysozyme level at different times of the day in 18 persons were: $6 \mathrm{am}: 1.35 \pm 0.42 \mathrm{mg} / \mathrm{ml} ; 10$ am: $1.44 \pm 0.39 \mathrm{mg} / \mathrm{ml} ; 2 \mathrm{pm}: 1.41 \pm 0.36 \mathrm{mg} / \mathrm{ml} ; 6$ pm: $1.47 \pm 0.36 \mathrm{mg} / \mathrm{ml}$; and $10 \mathrm{pm}: 1.52 \pm 0.32 \mathrm{mg} / \mathrm{ml}$. Analysis of variance (Table 2) showed that there was a significant variation in the lysozyme level in tears during the course of the day $(F=4.32$ for 4 and $68 \mathrm{df}$, $\mathrm{p}<0.01)$. It was found that, when individual comparisons were made, the differences in the lysozyme concentrations in tears that attained statistical significance at the $5 \%$ level were those between the concentration at 6 am and that at $6 \mathrm{pm}$ and between the concentration at $6 \mathrm{am}$ and that at $10 \mathrm{pm}$.

The mean lysozyme levels in tears over a period of one year in 22 individuals were: January: $1 \cdot 31 \pm 0 \cdot 46$ $\mathrm{mg} / \mathrm{ml}$; March: $1.23 \pm 0.36 \mathrm{mg} / \mathrm{ml}$; May: $1.31 \pm 0.33$ $\mathrm{mg} / \mathrm{ml}$; July: $1.29 \pm 0.33 \mathrm{mg} / \mathrm{ml}$; September: $1.30 \pm 0.29 \mathrm{mg} / \mathrm{ml}$; and November: $1 \cdot 21 \pm 0.28 \mathrm{mg} / \mathrm{ml}$. Analysis of variance showed that the variations were not statistically significant (Table 3 ). The mean

Table 2 Variation in tear lysozyme concentration during the day: analysis of variance

\begin{tabular}{lrrcr}
\hline $\begin{array}{l}\text { Source of } \\
\text { variation }\end{array}$ & $d f$ & $\begin{array}{c}\text { Total sum } \\
\text { of squares }\end{array}$ & $\begin{array}{l}\text { Mean sum } \\
\text { of squares }\end{array}$ & $F$ \\
\hline Between periods & 4 & $34 \cdot 27$ & $8 \cdot 57$ & $4 \cdot 32$ \\
Between individuals & 17 & $1068 \cdot 90$ & $62 \cdot 88$ & $31 \cdot 76$ \\
Error & 68 & 134.93 & $1 \cdot 98$ & \\
Total & 89 & $1238 \cdot 10$ & - & - \\
\hline
\end{tabular}

Table 3 Variation in concentration of lysozyme in tears over a period of time: analysis of variance

\begin{tabular}{lrcl}
\hline $\begin{array}{l}\text { Source of } \\
\text { variation }\end{array}$ & $d f$ & $\begin{array}{l}\text { Total sum } \\
\text { of squares }\end{array}$ & $\begin{array}{l}\text { Mean sum } \\
\text { of squares }\end{array}$ \\
\hline Between months & 5 & $0 \cdot 26$ & $0 \cdot 05$ \\
Within months & 126 & $63 \cdot 88$ & $0 \cdot 51$ \\
Total & 131 & $64 \cdot 14$ & - \\
\hline
\end{tabular}

'between months' sum of squares was less than the mean 'within months' sum of squares. No formal test of significance was, therefore, found to be necessary.

The tear lysozyme levels in both sexes in the different age groups are given in Table 1. It was noted that differences between males and females were not statistically significant in any of the age groups. The data for the two sexes were therefore pooled for each group before making comparisons by age. The mean lysozyme levels in tears in various age groups are given in Table 1 . The increase in the level of lysozyme in tears from the age group 2-15 years to 16-30 years was statistically significant $(\mathrm{p}<0 \cdot 001)$. Again, the fall in the level of tear lysozyme from the age group $31-45$ years to $46-60$ years and.from $46-60$ years to $61-78$ years was statistically significant $(p<0 \cdot 001)$.

\section{Discussion}

Valid comparisons of tear lysozyme level between healthy and diseased eyes are not possible without adequate control of biological variations. Several factors may influence the level of lysozyme in tears. A comprehensive study was therefore undertaken, and it showed that diurnal and age-related changes varied to an appreciable extent. There were no significant variations in the levels of tear lysozyme between the two eyes and at different times of the year.

Significant diurnal changes that we found in the level of tear lysozyme are interesting in that one earlier study ${ }^{15}$ showed no diurnal variation. No other study on diurnal variation is available for comparison. As regards variations in relation to sex, the present study is in agreement with the work of other investigators who found the level of tear lysozyme to be independent of sex. ${ }^{8101516}$

There are several reports on age-related changes in the level of tear lysozyme which are conflicting. ${ }^{8.101718}$ Some investigators have found that there is no effect of age on the tear lysozyme levels. ${ }^{8} 11161719$ Bonavida and Sapse ${ }^{211}$ found lower levels of tear lysozyme at the upper and lower extremes of age. Pietsch and Pearlman's observed that the level of lysozyme in tears fell continuously after the age of 10 years. Mukai' found that in healthy subjects tear lysozyme reached peak levels in the age group 11 to 20 years and tended to decrease thereafter. Mackie and $\mathrm{Seal}^{21}$ also noted a gradual decline of tear lysozyme levels with advancing age. Morsky and Aine $^{22}$ found a tendency to declining concentrations after 31-45 years of age. McGill et al. ${ }^{18}$ found that tear lysozyme levels started falling after the age of $\mathbf{4 0}$ years at a rate of $1 \mathrm{mg} / \mathrm{dl}(10 \mathrm{mg} / \mathrm{l})$ per year of age. Our study on a large number of subjects shows that the level of tear lysozyme tends to be low in the 
younger age group (2-15 years: $0.82 \mathrm{mg} / \mathrm{ml})$, rises and attains a plateau in the age group 16-45 years (16-30 years: $1.67 \mathrm{mg} / \mathrm{ml} ; 31-45$ years: $1.60 \mathrm{mg} / \mathrm{ml}$ ), and then falls significantly in later life $(46-60$ years: $1.26 \mathrm{mg} / \mathrm{ml}$; $61-78$ years: $1.01 \mathrm{mg} / \mathrm{ml}$ ) but still remains higher than that found in younger people. The earlier studies, where no alterations of tear lysozyme level with age were detected, were small and the methods used in them were less sensitive.

Our findings suggest that in studying the lysozyme levels in the tears of diseased people it is necessary to select separate controls matched for age from among healthy people for each disease group, and to collect all the tear samples at a particular time of the day, for valid comparisons to be made.

The statistical analysis was done by Mr G P Mathur, statistician, New Delhi Tuberculosis Centre, New Delhi.

\section{References}

1 Fleming A. On a remarkable bacteriolytic element found in tissues and secretions. Proc $R$ Soc Lond (Biol) 1922; 93: 306-10.

2 Selinger DS, Selinger RC, Reed WB. Resistance to infection of the external cye. The role of tears. Surv Ophthalmol 1979; 24: 33-9.

3 McEwen WK, Kimura SJ. Filter paper electrophoresis of tears. I. Lysozyme and its correlation with keratoconjunctivitis sicca. Am J Ophthalmol 1955; 39 (suppl): 200-2.

4 Minton LR. Paralimbal ring keratitis and absence of lysozyme in lupus erythomatosus. Am J Ophthalmol 1965; 60: 532-5.

5 Sapse AT, Bonavida B, Stone W Jr, Sercarz EE. Human tear lysozyme. III. Preliminary study on lysozyme levels in subjects with smog cye irritation. Am J Ophthalmol 1968; 66: 76-80.

6 van Bijsterveld OP. Diagnostic tests in the sicca syndrome. Arch Ophthalmol 1969; 82: 10-4.
7 El-Gammal MY, Salah M. Estimation of tear lysozyme in some eye diseases. Bull Ophthalmol Soc Egypt 1971; 64: 285-97.

8 Hirai T. Studies of lysozyme in tears. J Tokyo Womens Med Coll 1972; 42: 167-77.

9 Mukai M. Tear protein. Low molecular protein and lysozyme. Nippon Ganka Gakkai Zasshi 1975; 79: 607-13.

10 Avisar R, Menache R, Shaked P, Rubinstein J, Machtey I, Savir $\mathrm{H}$. Lysozyme content of tears in patients with Sjögren's syndrome and rheumatoid arthritis. Am J Ophthalmol 1979; 87: 148-51.

11 Mackie IA, Seal DV. The questionably dry eye. BrJ Ophthalmol 1981; 65: 2-9.

12 deLuise VP, Tabbara KF. Quantitation of tear lysozyme levels in dry eye disorders. Arch Ophthalmol 1983; 101: 634-5.

13 Sen DK, Sarin GS, Mani K, Saha K. Immunoglobulins in tears of normal Indian people. Br J Ophthalmol 1976; 60: 302-4.

14 Sen DK, Sarin GS. Immunoassay of human tear lysozyme. Am J Ophthalmol 1980; 90: 715-8.

15 Pietsch RL, Pearlman ME. Human tear lysozyme variables. Arch Ophthalmol 1973; 90: 94-6.

16 Janke W, Langmaack $H$, Tiburtius $H$. Bestimmung der lysozymalen Aktivität der Tranenflussigkeit mit klinisch anwendbaser Methode. Klin Monatsbl Augenheilkd 1973; 163: 366-9.

17 James WM. The lysozyme content of tears. Am J Ophthalmol 1935; 18: 1109-16.

18 McGill JI, Liakos GM, Goulding N, Seal DV. Normal tear protein profiles and age-related changes. Br J Ophthalmol 1984; 68: 316-20.

19 Regan E. The lysozyme content of tears. Am J Ophthalmol 1950; 33: 600-5.

20 Bonavida B, Sapse AT. Human tear lysozyme. II. Quantitative determination with standard Schirmer strips. Am J Ophthalmol 1968; 66: 70-6.

21 Mackie IA, Seal DV. Quantitative tear lysozyme assay in units of activity per microlitre. Br J Ophthalmol 1976; 60: 70-4.

22 Morsky P, Aine E. Determination of lysozyme in tears by immunoturbidimetric and optimised kinetic bacteriolytic method. Clin Chim Acta 1983; 129: 201-9.

Accepted for publication 19 July 1985. 